\title{
PEMIKIRAN HASAN AL-BANNA DALAM PENDIDIKAN ISLAM
}

\author{
Abdhillah Shafrianto \\ Sekolah Tinggi Ilmu Tarbiyah Raudhatul Ulum Sakatiga \\ Email:abdhilla@stit-ru.ac.id
}

\begin{abstract}
Abstrak
Pendidikan merupakan pemberian pengetahuan, keterampilan dan kebiasaan oleh pendidik kepada peserta didik melalui pengajaran, pelatihan dan lain sebagainya. Pendidikan dalam Islam merupakan pendidikan amal. Tujuan dari pendidikan Islam adalah terbentuknya kepribadian muslim, kemajuan masayarakat, dan budaya yang tidak menyimpang dari ajaran Islam. Sejarah telah menunjukkan bahwa perkembangan kegiatan pendidikan pada masa Islam terdahulu telah membawa kemajuan ilmu pengetahuan hingga ke masa modern. Akan tetapi saat ini, umat Islam tidak mewarisi semangat ilmiah yang dimiliki para pendahulunya. Akibatnya prestasi yang telah diraih berpindah tangan ke orang-orang barat, karena ternyata mereka mau mempelajari dan meniru tradisi keilmuan yang dimiliki oleh umat Islam masa terdahulu dan mampu mengembangkannya secara berlanjut. Kemudian, berawal dari kemunduran yang di alami umat Islam pada masa-masa itu dan orang-orang non muslim makin menunjukkan eksistensinya sebagai pusat peradaban, maka hadirlah banyak pemikir-pemikir Islam yang salah satunya yaitu Hasan al-Banna yang tersadar bahwa keadaan umat Islam saat itu sangat terbelakang. Berdasarkan uraian latar belakang yang telah penulis terangkan, maka penulis tertarik untuk melihat pemikiran beliau tentang pendidikan Islam. Adapun penelitian ini yang berupa penelitian pustaka, maka dalam proses penghimpunan datanya, maka penulis menghimpun data berupa informasi melalui literatur-literatur yang penulis peroleh di perpustakaan berupa buku-buku ataupun artikel-artikel yang penulis gunakan dalam mengkaji pengertianpengertian dan aspek-aspek pendidikan Islam menurut Hasan al-Banna. Mengingat penelitian ini adalah penelitian kualitatif, maka diadakan analisis data dengan menggunakan tiga pendekatan sebagai berikut: Pertama, pendekatan sejarah. Kedua, pendekatan deskriptif. Berdasarkan data yang diperoleh dan kemudian dianalisis, maka simpulan penelitian ini adalah: Pertama, Hasan al-Banna mempunyai pandangan bahwa pendidikan merupakan upaya ikhtiari manusia untuk peningkatan taraf hidup kearah yang lebih baik. Kedua, Pemikiran Hasan al-Banna dalam pendidikan Islam berangkat dari pemahamannya terhadap ajaran Islam yang memiliki universalitas; universalitas zamany, universalitas makany (geografi) dan unversalitas insany (kemanusiaan) yang berangkat dari al-Qur'an, Sunnah Nabi Saw dan amaliyat salaf al-shalih sebagai rujukannya. Ketiga, pemikiran pendidikan Islam dalam pandangan Hasan al-Banna meliputi; Dasar pendidikan dan metode pembelajaran harus berlandaskan al-Qur'an dan Sunnah. Tujuan pendidikan agar terbentuknya kepribadian muslim atas Islam yang kaffah. Materi pendidikan harus bertumpu pada ajaran tauhid, sedangkan ibadah dan akhlak merupakan suplemennya.
\end{abstract}

Kata Kunci: Hasan Albana, Pemikiran, Pendidikan, Islam 


\section{Pemikiran Al-Banna dalam Pendidikan Islam Abdhillah Shafrianto}

\section{Pendahuluan}

\section{Latar Belakang Masalah}

Pendidikan dapat diartikan perbuatan (hal, cara dan sebagainya) mendidik, dan berarti juga pengetahuan tentang mendidik, atau pemeliharaan (latihan-latihan dan sebagainya) badan, batin dan sebagainya (Nata, 2009: 333). Secara umum pendidikan dapat diartikan sebagai suatu usaha manusia untuk membina kepribadiannya sesuai dengan nilai-nilai di dalam masyarakat dan kebudayaan. Dengan demikian bagaimanapun sederhananya peradaban masyarakat, di dalamnya terjadi atau berlangsung suatu proses pendidikan. Oleh karena itu sering dinyatakan bahwa pendidikan telah ada sepanjang peradaban umat manusia. Pendidikan pada hakikatnya merupakan usaha manusia untuk melestarikan hidupnya (Ihsan dan Fuad Hasan, 2007: 28)

Pendidikan dalam Islam merupakan sekaligus pendidikan amal. Pembentukan kepribadian yang dimaksudkan untuk membentuk kepribadian muslim, kemajuan masyarakat dan budaya yang tidak menyimpang dari ajaran Islam. Islam memandang pendidikan sebagai pemberi corak hitam putihnya perjalanan hidup seseorang dan Islam juga menetapkan bahwa pendidikan yang wajib hukumnya bagi pria dan wanita, tiada batasan untuk memperolehnya, dan berlangsung seumur hidup semenjak buaian hingga ajal datang (Ihsan dan Fuad Hasan, 2007: 29).

Tujuan pendidikan Islam adalah menjadikan manusia agar mempergunakan semua sarana yang telah Allah sediakan sebagai jalan untuk beramal saleh dengan niat mencari ridha Allah. Ilmu yang didapatkan semata-mata digunakan untuk memaksimalkan potensi kebaikan agar dapat menjalankan amal saleh sebanyakbanyaknya dan memberi manfaat kepada sesama manusia, sehingga hal-hal yang merugikan selalu dapat dicegah (Thalib, 2008: 19).

Sejarah menunjukkan bahwa perkembangan kegiatan kependidikan pada masa klasik Islam telah membawa Islam sebagai jembatan pengembangan keilmuan dari keilmuan klasik ke keilmuan modern. Akan tetapi generasi umat Islam seterusnya tidak mewarisi semangat ilmiah yang dimiliki para pendahulunya. Akibatnya prestasi yang telah diraih berpindah tangan ke Barat, karena ternyata mereka mau mempelajari dan meniru tradisi keilmuan yang dimiliki oleh umat Islam masa klasik dan mampu mengembangkannya secara berlanjut. Kemudian, berawal dari kemunduran yang di alami umat Islam pada masa-masa itu dan Barat makin menunjukkan eksistensinya sebagai pusat peradaban, maka munculnya banyak pemikir-pemikir Islam salah satunya yaitu Hasan Al Banna yang tersadar bahwa keadaan umat Islam saat itu sangat terbelakang (Thalib, 2008: 19). Berdasarkan uraian latar belakang yang sudah penulis terangkan di atas, maka penulis lebih memilih untuk menjadikan sosok seorang Hasan Al Banna berikut juga pemikiranpemikiran beliau tentang pendidikan Islam.

\section{Rumusan Masalah}


Dari latar belakang yang sudah penulis kemukakan di atas, maka penulis dapat merumuskan permasalahan-permasalahan yang akan dipaparkan adalah sebagai berikut:

a. Bagaimana biografi Hasan al-Banna?

b. Bagaimana pemikiran Hasan al-Banna tentang pendidikan Islam?

\section{Tujuan Penelitian}

Dalam penelitian ini, ada beberapa tujuan yang ingin dicapai oleh penulis, yaitu:

a. Untuk mengetahui biografi Hasan al-Banna?

b. Untuk mengetahui pemikiran Hasan al-Banna tentang pendidikan Islam?

\section{Kegunaan Penelitian}

a. Secara Teoritis

1) Untuk menambah pengetahuan dan wawasan bagi para pembaca, para orang tua, masyarakat dan penulis khususnya.

2) Diharapkan bisa menjadi rujukan bagi pendidik dan orang tua dalam menerapkan sistem pendidikan Islam bagi anak-anak dan siswa mereka.

b. Secara Praktis

1) Hasil penelitian ini diharapkan dapat memberikan kontribusi terhadap perkembangan ilmu pengetahuan khususnya ilmu pendidikan Islam.

2) Hasil penelitian ini diharapkan dapat digunakan sebagai bahan acuan dalam penyelenggaraan pendidikan Islam khususnya dan pendidikan nasional pada umumnya agar tercapai pendidikan Islam yang sempurna.

\section{Metode Penelitian}

a. Jenis Penelitian

Penelitian adalah cara ilmiah, berarti penelitian itu didasarkan pada ciri-ciri keilmuwan yaitu rasional, empiris dan sistematik. Rasional artinya kegiatan penelitian itu dilakukan dengan cara-cara yang masuk akal sehingga terjangkau oleh penalaran manusia. Empiris artinya cara-cara yang digunakan dalam penelitian teramati oleh indera manusia, sehingga orang lain dapat mengamati dan mengetahui cara-cara yang akan digunakan. Sistematis artinya proses yang digunakan dalam penelitian itu menggunakan langkah- langkah tertentu yang bersifat logis (Sugiyono, 2011: 1).

Adapun jenis penelitian ditinjau dari tempatnya secara garis besar diklasifikasikan menjadi dua macam, yaitu penelitian pustaka atau kajian pustaka (library research) dan penelitian lapangan. Berdasarkan pembagian tersebut maka jenis penelitian dalam kajian ini dilihat dari tempat penelitian ini dilakukan yaitu perpustakaan (Sugiyono, 2011: 16). Adapun penelitian ini yang berupa penelitian pustaka, maka dalam proses penghimpunan datanya, maka penulis menghimpun data berupa informasi melalui literatur-literatur yang penulis peroleh di 


\section{Pemikiran Al-Banna dalam Pendidikan Islam Abdhillah Shafrianto}

perpustakaan berupa buku- buku ataupun artikel-artikel yang penulis gunakan dalam mengkaji pengertian-pengertian, dan aspek-aspek pendidikan Islam menurut Hasan Al Banna.

\section{b. Metode Pengumpulan Data}

Adapun metode yang penulis gunakan dalam pengumpulan data dalam penelitian ini adalah:

1) Metode studi kepustakaan, adalah metode dimana data dikumpulkan melalui studi keperpustakaan, yakni dengan mencari, membaca, mempelajari dan mengkaji terhadap materi-materi yang dibahas dari bermacam-macam sumber data yang berkaitan dengan permasalahan yang hendak diteliti (Sukardi, 2014: 34).

2) Metode dokumentasi, adalah penelitian yang dilakukan dengan mencari data mengenai hal-hal atau variabel yang berupa catatan, transkip, buku, surat kabar, majalah, prasasti, notulen rapat, legger, agenda dan sebagainya (Arikunto, 2013: 161).

c. Data dan Sumber Data

Data adalah hasil pencatatan peneliti, baik yang berupa fakta ataupun angka. Adapun yang dimaksud dengan sumber data dalam penelitian ini adalah subjek dari mana data diperoleh. Apabila peneliti menggunakan dokumentasi, maka dokumen atau catatanlah yang menjadi sumber data, sedang isi catatan subjek penelitian atau variabel penelitian (Arikunto, 2013: 172).

1) Sumber Data

Terdapat dua sumber data yang akan menentukan bagaimana suatu proses pengumpulan data yang akan dilakukan. Adapun sumber data dalam penelitian ini adalah sebagai berikut:

a) Data Primer

Data primer merupakan sebuah data yang dikumpulkan berdasarkan interaksi langsung antara pengumpul dan sumber data (Nahartyo dan Utami, 2016: 51). Data primer yang penulis gunakan dalam penelitian ini adalah data pokok yang diperoleh yang meliputi sumber-sumber referensi berupa buku-buku karangan Hasan al-Banna maupun buku-buku karangan orang lain yang menulis tentang pemikiran Hasan al-Banna. Dalam penelitian ini penulis menggunakan buku "Pemikiran Hasan al-Banna Tentang Pendidikan".

b) Data sekunder

Data sekunder adalah data yang diperoleh atau bersumber dari tangan kedua (second hand data) (Sudijono, 2012: 19). Data sekunder adalah data yang dikumpulkan dari sumber-sumber tercetak, dimana data tersebut telah dikumpulkan oleh pihak lain sebelumnya. Contoh sumber data sekunder ini adalah buku, laporan perusahaan, jurnal, internet dan sebagainya (Nahartyo dan Utami., 2016: 5).

2) Teknik Pengumpulan data 
Teknik pengumpulan data yang penulis pakai dalam skripsi ini adalah dengan cara mencari, membaca, mengumpulkan dan menganalisis dokumen- dokumen yang berhubungan dengan penelitian ini. Dokumen yang penulis pakai dalam teknik pengumpulan data adalah dokumen tertulis berupa buku-buku atau literatur yang berhubungan dengan masalah yang sedang diteliti dan dokumen cetak berupa jurnal.

\section{d. Analisis Data Penelitian}

Setelah penulis melakukan pengumpulan data dari berbagai sumber berupa buku karangan Hasan al-Banna dan buku-buku yang berhubungan dengan aspekaspek pendidikan juga beberapa pendapat ahli di bidangnya masing-masing kemudian dianalisa secara cermat, teliti dan ulet, sehingga nantinya akan didapatkan kesimpulan yang objektif dari hasil penelitian yang telah dilakukan.

Adapun cara berpikir yang penulis gunakan dalam menganalisa data adalah cara berpikir deduktif. Cara berpikir deduktif ialah suatu bentuk pendekatan pemikiran yang mengutamakan langkah awal dari pengetahuan umum yang telah diverifikasikan yang kemudian akan memperoleh bentuk kesimpulan yang sifatnya lebih spesifik (Sukardi, 2014: 33). Mengingat penelitian ini adalah penelitian kualitatif, maka diadakan analisis data dengan menggunakan tiga pendekatan sebagai berikut:

1) Pendekatan Sejarah.

Dengan ini penulis bermaksud untuk menggambarkan sejarah biografis dari Hasan Al Banna yang meliputi riwayat hidup, pendidikan, latar belakang pemikiran serta karya-karyanya Melalui pendekatan ini peneliti memfokuskan pencarian data dengan metode dokumentasi melalui buku-buku yang berkaitan erat dengan peristiwa yang sedang diteliti sehingga memperoleh gambaran secara objek gambaran secara objektif terhadap objek yang sedang diteliti (Sukardi, 2014: 33).

2) Pendekatan Deskriptif.

Pendekatan ini dimaksudkan untuk menyelidiki keadaan, kondisi atau hal lain-lain yang sudah disebutkan, yang hasilnya dipaparkan dalam bentuk laporan penelitian. Dengan ini peneliti hanya memotret apa yang terjadi pada diri objek atau wilayah yang diteliti, kemudian memaparkan apa yang terjadi dalam bentuk laporan penelitian secara lugas, seperti apa adanya (Arikunto, 2013:3).

\section{Pembahasan}

1. Biografi Hasan al-Banna

Al-Banna dilahirkan di kota kecil Mahmudiyah di muara Sungai Nil, sembilan puluh mil di sebelah barat laut Kairo, pada tahun 1906 (Kholiq, 1999: 253). Julukannya adalah Pembaharu Islam Abad ke-20 (Mursi, 2007: 244). Ayahandanya, bernama Syeikh Ahmad Abdurrahman al-Banna, yang lebih terkenal dengan panggilan as-Sa'ati, atau si tukang arloji. Syeikh Ahmad sehari-harinya di samping sebagai tukang reparasi arloji juga merangkap sebagai imam masjid dan guru agama di masjid setempat. Syeikh Ahmad menguasai ilmu fiqh, ilmu tauhid, ilmu bahasa dan menghafal al-Qur'an. Bahkan Syeikh Ahmad pernah belajar sebagai mahasiswa 


\section{Pemikiran Al-Banna dalam Pendidikan Islam Abdhillah Shafrianto}

al-Azhar pada waktu Muhammad Abduh mengajar di lembaga itu. Sehingga tak mengherankan jika ia disegani oleh sejumlah besar ulama di Mesir.

Hasan al-Banna lahir dari keluarga yang cukup terhormat dan dibesarkan dalam suasana keluarga yang taat. Sebagai seorang ayah, Syeikh Ahmad mencitacitakan putranya (Hasan) sebagai mujahid (pejuang) disamping seoarang mujaddid (pembaharu). Sejak kecil Hasan al-Banna telah dituntut untuk menghafalkan alQur'an penuh. Baru setelah itu ia di masukkan sekolah persiapan yang dirancang pemerintah Mesir menunit model sekolah dasar, tanpa pelajaran bahasa asing. Dan ketika di rumah Hasan bergelut dengan perpustakaan pribadi ayahnya, yang berisi buku agama, hukum, hadis dan ilmu bahasa (Kholiq, 1999: 253).

Pada usia 14 tahun (1920), Hasan al-Banna masuk sekolah guru tingkat pertama di Damanhur. Dan dalam usia itu pula Hasan al-Banna juga menjadi anggota aktif golongan sufi Hasafiyah dan tetap aktif di jamiyah tersebut sampai dua puluh tahun berikutnya. Sejak di sekolah menengah hasan sudah terpilih sebagai ketua Jam"iyatul Ikhwanial-adabiyah, yakni sebuah perkumpulan yang terdiri dari calon pengarang. Ia juga mendirikan dan sebagai ketua Jam"iyatul Man"il Muharramat, semacam serikat pertobatan serta pendiri dan sekretaris Jam'iyatul Hasafiyah Khairiyah, semacam organisasi pembaharuan. Kemudian ia juga menjadi anggota Makarimul Akhlaqil Mukarramah, yaitu Perhimpunan Etika Islam. Pada usia enam belas tahun, ia pergi ke Kairo untuk melanjutkan sekolah guru bahasa Arab, sebuah lembaga pendidikan produk abad pembaharuan yang berdiri pada abad 19 dan boleh dikatakan sebagai miniatur al-Azhar. Dalam lingkungan pendidikan tersebut Hasan al-Banna mampu mengorganisasikan kelompok mahasiswa Universitas al-Azhar dan kelompok mahasiswa Universitas Dar al-Ulum yang melatih diri berkhotbah di masjidmasjid. Dalam kesempatan belajar di Kairo, Hasan Al Banna sering berkunjung ke toko-toko buku yang dimiliki oleh gerakan Shalafiyah pimpinan Rasyid Ridha. Di Mesir pula ia aktif membaca al-Manar dan berkenalan dengan Rasyid Ridha serta menjalin komunikasi dengan murid-murid Abduh lainnya.

Pada tahun 1927, saat usia Hasan al-Banna mencapai 21 tahun, ia lulus dari alUlum dan mendapat tugas sebagai guru Sekolah Dasar Ismailiyah markas besar Perusahaan Terusan Suez yang dikuasai oleh Inggris.

Pada bulan Maret 1928, di kota Ismailiyah, ia mendirikan Gerakan Ikhwanul Muslimin (Kholiq, 1999: 253-254). Dia membentuk Ikhwanul Muslimin dengan tujuan memulai gerakan revolusioner untuk memandu bangsanya yang salah arah. Anggota Ikhwanul Muslimin adalah orang-orang yang berdedikasi dan beriman sehingga mereka tidak akan menyimpang dari prinsip-prinsip. Mereka mengunjungi semua rumah dan berusaha meyakinkan penghuni rumah untuk bergabung dengan mereka dan menghindari gemerlap dunia dan nilai-nilai Barat (Haque, 2007: 376). Pada mulanya ia hanya memiliki enam orang pengikut dan sekelompok siswa yang taat kepada guru. Tapi dalam perkembangannya gerakan ini setapak demi setapak mulai mendapatkan simpati dari masyarakat. Gerakan Ikhwanul Muslimin yang pada mulanya memfokuskan perhatian pada bidang sosial 
P-ISSN : 2541-3686

dan pendidikan bahkan pada akhirnya menjelma sebagai kekuatan politik yang dikagumi di Mesir dan dunia Arab.

Gerakan ini dalam perjalanan perjuangannya di Mesir akhirnya mengalami beberapa hambatan dari pemerintahan Mesir sendiri, setelah kekhawatiran pemerintah atas keterlibatan Ikhwanul Muslimin dalam agitasi dan kekerasan, tepatnya pada tahun 1948, ketika pecah perang Palestina dan peran Mesir yang mengecewakan.

Puncaknya tanggal 8 Desember 1948, dengan keluar perintah militer yang berisi pembubaran Ikhwanul Muslimin dan cabangnya di mana saja, menutup pusatpusat kegiatannya, menyita koran, dokumen, majalah dan semua publikasinya serta uang dan kekayaan Ikhwanul Muslimin. Kebijaksanaan pemerintah tersebut juga dibarengi dengan penangkapan dan pengahalauan para pejuang dan tokoh-tokoh Ikhwan ke kamp-kamp konsentrasi dan penjara.

Hasan al-Banna masih mencoba mendekatkan pengertian untuk menjernihkan masalah, tapi pada tanggal 28 Desenber 1948, perdana menteri anNuqrasy terbunuh, dan tuduhan dialamatkan ke kelompok Ikhwan, dan menjadikan kondisi bertambah parah. Tujuh minggu setelah kejadian tersebut pada tanggal 12 Februari 1949, Hasan al-Banna dibunuh oleh agen-agen dinas rahasia Mesir (Kholiq, 1999: 254-255).

Peristiwa itu terjadi pada masa Ibrahim Abdul Hadi yang menggantikan Nuqrasy sebagai perdana menteri dengan bekerjasama dengan istana dan agen imperialis Inggris. Setelah tewasnya Hasan al-Banna terjadilah penangkapan dan penyiksaan serta pembunuhan besar-besaran kepada anggota Ikhwanul Muslimin (Said, 2003: 167).

Imam Asy-Syahid mempunyai beberapa murid seperti, Yusuf AlQardhawi, Syaikh Mutawalli Sya'rawi, Musthafa As-Siba'i, Abdul Qadir Audah, Umar AtTilmisani, Mustafa Masyhur dan lain-lainnya (Mursi, 2007: 248). Ia mewariskan dua karya monumentalnya, yaitu Mudzakkirat al-Dakwah wa Da'iyyah (Catatan Harian Dakwah dan Da'i), dan Majmu "ah Rasail (Kumpulan Surat-Surat). Selain itu, Hasan al-Banna mewariskan semangat dan teladan dakwah bagi seluruh aktivis dakwah sepanjang zaman (Mohammad, dkk, t.th: 207-66).

\section{Pemikiran pendidikan Hasan al-Banna}

Sistem pendidikan yang diterapkan Hasan Al Banna dalam Madrasah Hasan al-Banna berbeda kontras dengan sistem pendidikan yang dibangun oleh dasar individualis maupun sosialis komunis. Bahkan pendidikan al-Banna dalam masyarakat yang diatur oleh al-Qur'an dan di dalamnya dominan ajaran-ajaran Islam berbeda pula dengan pendidikan muslim yang di dalamnya terdapat ide sekuler. Sistem pendidikan yang dibangun Hasan al-Banna mengacu kepada tujuan yang jelas, langkah-langkah yang nyata, sumber yang terang yang digali dari ajaran Islam kaffah bukan dari ajaran yang lainnya. Komponen-komponen pemikiran 


\section{Pemikiran Al-Banna dalam Pendidikan Islam Abdhillah Shafrianto}

Hasan Al Banna tentang pendidikan yang diaplikasikan dalam Madrasah Hasan Al Banna adalah sebagai berikut:

a. Dasar-dasar Pendidikan

Madrasah Hasan al-Banna dibangun dengan landasan agama Islam yang bersumber pada al-Qur'an dan tafsirnya, terutama mengutamakan tafsir salaf seperti Tafsir Ibnu Katsir. Sumber yang kedua adalah al-Hadist dengan keauntentikan dan syarahnya berpegang pada imam-imam hadist yang terpercaya. Dalam pandangan Hasan, bahwa kedua sumber tersebut adalah tempat kembali setiap muslim untuk mengetahui hukum Islam. Dan keduanya sebagai dasar Islam harus dipahami secara total dan universal sebagaimana mestinya dengan memperhatikan keautentikan dan kevalidannya.

Madrasah Hasan al-Banna mendasarkan pembentukan kepribadian, mengacu pada pemahaman Islam yang sempurna dan universal "total islam", sebagaimana yang terkandung di dalam al-Qur'an dan al-Hadist. Hal ini didasarkan atas pemahaman Hasan al-Banna tentang Islam yang dipahami sebagai peraturan yang menyeluruh yang mencakup setiap aspek kehidupan, meliputi negara dan tanah air, pemerintahan dan bangsa, penciptaan dan kekuasaan, rahmat dan keadilan, budaya dan hukum, ilmu pengetahuan dan ketetapan, jihad dan seruan menuju Allah, angkatan bersenjata dan pemikiran serta ritual keagamaan.

Dengan memahami sumber Islam yakni al-Qur'an dan al-Hadist secara autentik dan kaffah maka Islam dipahami sebagai tatanan yang lengkap dan menyeluruh yang mencakup setiap aspek kehidupan. Pemahaman Islam kaffah tersebut menjadi dasar utama sistem pengajaran Madrasah Hasan Al Banna sehingga corak pengajarannya mempunyai nilai keuniversalan khususnya untuk membangun masyarakat Islam yang benar-benar menerapkan Islam secara total dan universal (Kholiq, 1999: 255-256).

b. Tujuan Pendidikan

Pada hakekatnya tujuan pendidikan Madrasah Hasan al-Banna merupakan suatu perwujudan dari nilai-nilai ideal yang terbentuk dalam pribadi manusia yang dikehendaki, yang mempengaruhi dan menggejala dalam prilaku, berorientasi untuk merealisasikan identitas Islami, yaitu membentuk kepribadian muslim (Kholiq, 1999: 256). Hasan al-Banna sering mengatakan bahwa pendidikan (tarbiyah) adalah upaya ikhtiari manusia untuk merubah kondusi ke arah yang lebih baik. Beliau berkata; Pendidikan (tarbiyah) harus menjadi pilar kebangkitan, oleh karenanya umat Islam harus terdidik, dengan itu akan mengerti hak-haknya yang harus diterimanya secara utuh, dan mempelajari berbagai sarana agar dapat memperoleh hak-hak tersebut (Ruslan, 2000: 39).

Mencermati kutipan di atas, setidaknya ada tiga hal yang sangat mendasar dan perlu digaris bawahi yang berkaitan dengan pendidikan umat Islam :

1) Umat Islam tidak boleh menjadi umat yang bodoh, ia harus punya pendidikan.

2) Umat Islam harus mengetahui dan menjalankan kewajiban-kewajibannya, dengan itu ia akan mengetahui akan hak-hak yang harus menjadi miliknya. 
Volume 4 Nomor 2 Edisi Desember 2019

P-ISSN : 2541-3686

3) Umat Islam tidak hanya dituntut punya pengetahuan teoritis, tapi juga keterampilan (skill) sebagai saran memperoleh hal-hal yang berkenaan dengan haknya.

\section{c. Metode Pendidikan}

Menurut Hasan Al Banna, metode pendidikan harus seirama dengan konsep dan martabat manusia sebagai khalifah Allah. Artinya, metode dan pendekatan dalam pendidikan haruslah mencontoh prinsipprinsip Qur'ani, yaitu :

1) Bersifat komprehensif, yaitu satu sama lain saling mengisi.

2) Mampu mendidik manusia untuk layak berintegrasi bagi kehidupan dunia akhirat.

3) Mengakui adanya kekuatan dalam diri manusia, ruh, akal, jasmani, dan bekerja demi memenuhi kebutuhannya.

4) Siap untuk diterapkan, artinya tidak terlalu idealis dan mungkin diikuti dan diterapkan oleh manusia.

5) Metode praktik, bukan sekedar teoritis.

6) Bersifat kontinue, sesuai bagi seluruh manusia dan berlangsung sampai manusia menemui Rabbnya.

7) Menguasai seluruh perkembangan dalam hidup manusia, mencapai batasan yang mampu diakses oleh manusia dengan kekuatan yang dimilikinya (Mahmud, 2000: 53-54).

\section{Pendidik dan Peserta Didik}

Tentang hubungan pendidik dengan peserta didik menurut pemikiran Hasan al-Banna dapat terbaca dari cuplikan-cuplikan pidato dan surat-surat yang ia kirimkan kepada anggota-anggota dan simpatisan al-Ikhwan al-Muslimin yang selalu memakai tema "al-ikhwan" (Al-Banna, 1411: 59), kata "nahnu dengan arti "kita", dan memakai kata kerja berawalan "nun" (fill mudhari), seperti" na "taqidu نتنق dengan arti kita meyakini, nunadihim dengan arti kita ajak mereka, dan lain-lain.

Hubungan yang dekat antara Hasan al-Banna dengan jamaahnya merupakan refleksi dari pemikirannya tentang perlunya membangun hubungan yang erat antara murabby dengan murabba. Hubungan antara murabby (Tuhan) dengan murabba (alam semesta) merupakan manifestasi dari pemahamannya terhadap potongan ayat "alhamdu lillaahi robbil aalamin". Suatu hubungan yang melambangkan kasih tanpa pilih terhadap anak-anak didik yang notabenenya mereka berasal dari berbagai strata kehidupan dan kemampuan yang variatif.

Kehangatan hubungan antara seorang pendidik dengan anak didik merupakan suatu hal yang krusial yang mestinya diwujudkan dalam pendidikan, sebab hal itu menurut sebuah penelitian akan memberikan pengaruh positif terhadap usaha belajar siswa/anak didik (Prayitno, 1990: 578). Shalaluddin Jursyi mengatakan, Hasan Al Banna itu lebih menonjol kemampuan memimpinnya dan 


\section{Pemikiran Al-Banna dalam Pendidikan Islam}

\section{Abdhillah Shafrianto}

mendidik umat dengan berbagai kecakapan yang dimilikinya dan ia selalu berperan sebagai orang tua dalam hubungannya dengan para pengikutnya (Jursy, 2004: 60).

Suatu hal yang rasanya perlu dicatat terutama bagi pengelola pendidikan terutama bagi orang-orang yang berkiprah di dunia pendidikan. Menurut beliau, hendaklah ditangani oleh orang yang punya kekuatan jiwa, tekad yang kuat dan semangat yang tegar. Memiliki kesetiaan yang utuh, bersih dari sikap lemah dan jauh dari sifat munafik. Punya sifat rela berkorban, tidak mudah diperdayakan oleh hal-hal material dan jauh dari sifat serakah (Al-Banna, 1411: 97). Seluruhnya merupakan kompetensi kpribadian yang hams dimiliki setiap individu yang bergerak dalam dunia pendidikan.

Hal yang perlu diteladani dari pemikiran Hasan Al Banna terutama dalam hal hubungan pendidik dengan peserta didik yang merupakan gambaran kompetensi kepribadian adalah, mendidik dengan hati dan selalu mendoakan anak didik. Dalam hal kelemah lembutan, Saiful Islam anak kedua dari Hasan Al Banna-Sekjen Aliansi Advokat dan anggota Parlemen Mesir menuturkan: "Ayah mengajari kami dengan penuh cinta kasih, ketulusan, kelembutan dan penuh rasa harap."(Aulia, 2007: 39) 
RAUDHAH Proud To Be Professionals Jurnal Tarbiyah)damiyah

Volume 4 Nomor 2 Edisi Desember 2019

P-ISSN : 2541-3686

\section{DAFTAR PUSTAKA}

Al-Banna, Hasan. Majmu 'at Rasa „il al-Imam al-Syahid Hasan al-Banna, Kairo: Dar al Da'wah, $1411 \mathrm{H}$

Ali Abd. Halim Mahmud, Pendidikan Ruhani, terj. Abdul Hayyie al-Kattani, Jakarta: Gema Insani Press, 2000

Aravik, Havis, Pengantar Studi Islam, Palembang: Rafah Press, 2018.

Arikunto, Suharsimi Prosedur Penelitian, Suatu Pendekatan Praktik, Jakarta : PT Rineka Cipta, 2013

Haque, M. Atiqu. Seratus Pahlawan Muslim yang Mengubah Dunia, Jogjakarta: Diglossia, 2007

Ihsan, Hamdani \& Ihsan, Fuad. Filsafat Pendidikan Islam Bandung : CV Pustaka Setia, 2007

Jursyi, Shalaluddin. Membumikan Islam Progresif, terj. M. Aunul Abiet Syah, Muhammad Lili Nur Aulia. Cinta di Rumah Hasan al-Banna, Jakarta: Puslaka Da'watuna, 2007

Kholiq, Abdul. Pemikiran Pendidikan Islam Kajian Tokoh Ktasik dan Kontemporer, Semarang: Fakultas Tarbiyah IAIN Walisongo Semarang bekerjasama dengan Pustaka Pelajar, 1999

Mursi, Muhammad Saeid. Tokoh-tokoh Besar Islam Sepanjang Sejarah. Jakarta; Pustaka Al-Kautsar, 2007

Nahartyo, Ertambang \& Utami, Intiyas. Panduan Praktis Riset Eksperimen, Jakarta : PT Indeks, 2016

Nata, Abuddin. Metodologi Studi Islam, Jakarta : PT Raja Grafindo Persada, 2009

Prayitno, Elida. Rekonstruksi Mata Kuliah Dasar Kependidikan, Padang: IKIP, 1990

Said, Imam Al-Ghazali. Ideologi Kaum Fundamentalis, Pengamh Politik al-Maududi Terhadap Gerakan Jamaah islamiyyah Trans Pakistan-Mesir, Surabaya: Diantara, 2003

Sudijono, Anas. Pengantar Statistika Pendidikan, Jakarta: PT Raja Grafindo Persada, 2012

Sugiyono, Statistika untuk Penelitian, Bandung : Alfabeta, 2011

Sukardi, Metodologi Penelitian Pendidikan Kompetensi dan Praktiknya, Jakarta : PT Bumi Aksara, 2014

Thalib, Muhammad. Ensiklopedi Keluarga Sakinah; Kiat dan Seni Mendidik Anak, Yogyakarta : Pro-U Media, 2008. 
Pemikiran Al-Banna dalam Pendidikan Islam

Abdhillah Shafrianto 